\title{
STRUKTUR KOMUNITAS SPONS DI PERAIRAN LALANU KECAMATAN SOROPIA, SULAWESI TENGGARA
}

\section{Sponge Community Structure in Lalanu Seawaters, Soropia of Southeast Sulawesi}

\author{
Sitti Rahmawati Rahman ${ }^{1}$, Baru Sadarun ${ }^{2}$, Rahmadani $^{3}$ \\ ${ }^{1}$ Mahasiswa Jurusan Ilmu Kelautan, \\ Fakultas Perikanan dan Ilmu Kelautan, Universitas Halu Oleo. \\ Jl. H.E.A Mokodompit Kampus Hijau Bumi Tridharma Anduonohu Kendari 93232, Telp/Fax: (0401) 3193782 \\ ${ }^{2}$ Surel: sadarunbaru@gmail.com \\ ${ }^{3}$ Surel: rahmamustafa47@gmail.com
}

\begin{abstract}
Abstrak
Spons merupakan hewan yang memberikan sumbangan penting terhadap komunitas benthic laut. Keberadaannya mampu menjadi bioindikator kualitas perairan laut karena sifatnya yang menetap. Penelitian ini dilaksanakan pada bulan Oktober 2018 dan bertujuan untuk mengetahui komposisi jenis dan mengetahui struktur komunitas spons yang meliputi indeks keanekaragaman, keseragaman, dominansi yang ada di Perairan Lalanu. Pengambilan data dilakukan dengan menggunakan metode Belt transect dengan panjang $70 \mathrm{~m}$ dan lebar $2 \mathrm{~m}$ sehingga luas pengamatan $140 \mathrm{~m}^{2}$ pengambilan data dilakukan 2 kali pengulangan. Jenis spons yang ditemukan di Perairan Lalanu 16 jenis, dimana komposisi jenis tertinggi terdapat pada spesies Petrosia sp., baik di daerah reef flat maupun daerah reef slope. Struktur kominitas spons pada Perairan Lalanu di daerah reef flat dan reef slope didapatkan hasil dengan kategori yang sama. Dimana indeks keanekaragaman dengan kategori sedang, indeks keseragaman dengan kategori tinggi dan indeks dominansi dengan kategori rendah.
\end{abstract}

Kata kunci : Komposisi Jenis, Perairan Lalanu, Spons, Struktur Komunitas

\begin{abstract}
Sponges are marine animals which play an important role in marine benthic communities. Its existence is a bioindicator of water quality because of its sedentary characteristic. This study aimed to determine composition and community structure of sponge which consisted of diversity, uniformity, dominance indexin Lalanu waters. Belt Transect method with $70 \times 2 \mathrm{~m}$ and 2 repetitions was applied to collect data. 16 types of sponges werefound in the study area. The highest species composition wasPetrosiasp both in reef flat and in reef slope areas. There was no difference based on community structure both in reef flat and in reef slope. The diversity index was in moderate category, the uniformity index was in the high category and the dominance index was in low category.
\end{abstract}

Kata kunci : Composition, community structure, Lalanu Waters, Sponge.

\section{Pendahuluan}

Potensi sumber daya pesisir yang ada di Sulawesi Tenggara sangat melimpah salah satunya yaitu potensi ekosistem terumbu karang yang terdapat di Perairan Lalanu Kecamatan Soropia. Perairan Lalanu merupakan suatu perairan yang berada di Kecamatan Soropia Kabupaten Konawe. Desa Lalanu merupakan desa pemekaran dari Desa Atowatu, dimana pada bagian barat berbatasan dengan Desa Soropia dan sebelah selatan berbatasan dengan Desa Nipa-nipa.

Berbagai macam biota dapat ditemui pada ekosistem terumbu karang, salah satunya yaitu dari filum porifera. Porifera adalah hewan multiseluler yang paling sederhana, hewan ini memiliki ciri-ciri antara lain seperti tubuhnya berpori seperti busa atau spons sehingga porifera disebut juga sebagai hewan spons. Porifera selalu melekat pada substrat (sesil) dan tidak dapat berpindah tempat secara bebas (Lariman, 2010).

Spons merupakan salah satu komponen biota penyusun terumbu karang yang penyebarannya cukup luas. Komunitas spons disuatu wilayah perairan mampu menjadi salah satu bioindikator kualitas perairan laut karena sifatnya yang menetap (Acker and Moss, 2007). Sehingga mengharuskan spons tersebut untuk selalu dapat beradaptasi terhadap komponen-komponen fisik maupun komponen biotik yang terdapat pada wilayah tersebut (Alcolado, 2003).

Spons merupakan hewan yang memberikan sumbangan penting terhadap komunitas benthik laut. Selain itu, keberadaan spons saat ini menjadi perhatian besar bagi 
para peneliti karena kandungan senyawa aktif dalam tubuh spons. Selain sebagai sumber senyawa bahan alam, spons juga memiliki manfaat lain, yakni digunakan sebagai indikator biologi seperti pemantauan pencemaran laut, indikator dalam interaksi komunitas, dan sebagai hewan yang bernilai ekonomis (Suparno, 2005).

Spons juga merupakan salah satu biota perairan yang sangat besar manfaatnya dan juga dapat dijadikan sebagai objek wisata bawah laut. Keberadaan spons dapat menjadi daya tarik tersendiri bagi para nelayan yang nantinya dapat menjadi nilai lebih dari suatu daerah. Spons yang sudah mati dapat dimanfaatkan sebagai penggosok ketika mandi atau mencuci. Selain itu, dapat juga dimanfaatkan sebagai hiasan yang ada pada akuarium, sebagai makanan hewan laut lainnya, sebagai sarana kamuflase bagi beberapa hewan laut dan juga sebagai campuran bahan kosmetik (Fosifpunila, 2000).

\section{Bahan dan Metode}

Pengambilan data spons dilaksanakan pada bulan Oktober 2018 dan bertempat di Perairan Lalanu. Lokasi terletak pada 3 stasiun pengamatan yang ditentukan dengan melakukan survei lapangan untuk melihat langsung lokasi yang cocok untuk ditempatkan titik stasiun dan menandai koordinat menggunakan GPS (Global Positioning System). Peta lokasi penelitian selengkapnya disajikan pada Gambar 1.

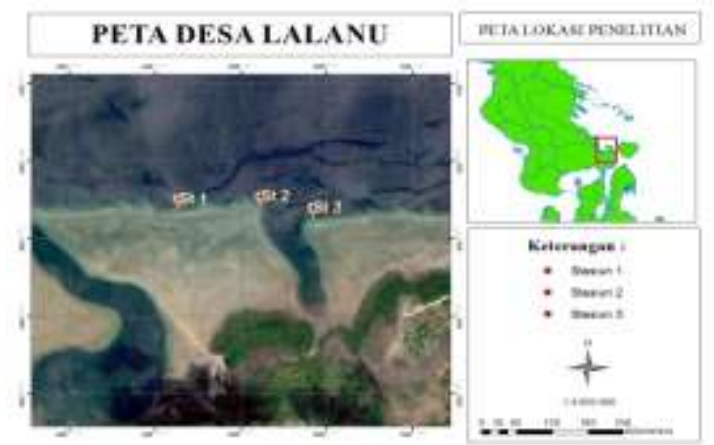

Gambar 1. Sketsa lokasi penelitian

Survei pendahuluan dilakukan untuk melihat kondisi lokasi penelitian secara menyeluruh. Hal ini bertujuan untuk melihat kondisi awal lokasi penelitian sebagai pertimbangan dalam menentukan stasiun penelitian. Penelitian ini dilakukan dengan snorkling untuk melihat keberadaan organisme spons.

Penentuan titik stasiun penelitian dilakukan berdasarkan survei pendahuluan dengan menggunakan metode "purposive Sampling" yaitu penentuan stasiun dengan memperhatikan pertimbangan kondisi lingkungan dan keberadaan organisme spons di daerah penelitian. Pengamatan spons ditetapkan sebanyak 3 (tiga) titik stasiun penelitian. Stasiun I, terletak pada $3^{\circ} 53^{\prime} 18.90^{\prime \prime} \mathrm{LS}-122^{\circ} 36^{\prime} 46.59^{\prime \prime} \mathrm{BT}$, stasiun ini mengarah kea rah laut lepas. Stasiun II, terletak pada $3^{\circ} 53^{\prime} 18.59^{\prime \prime} \mathrm{LS}$

$122^{\circ} 366^{\prime} 57.68$ "BT, stasiun ini mengarah kea rah laut lepas dan berada pada kaki mulut sungai. Stasiun III, terletak pada $3^{\circ} 53^{\prime} 20.41^{\prime \prime L S}$ - $122^{\circ} 37^{\prime} 4.69^{\prime \prime} \mathrm{BT}$, stasiun ini letaknya dekat dengan vegetasi mangrove dan berada tidak jauh dengan kaki mulut sungai.

Pengambilan data suhu di setiap stasiun dilakukan secara langsung menggunakan alat thermometer, Suhu yang diukur adalah suhu permukaan. cara mengukurnya yaitu ujung thermometer dicelupkan ke dalam badan perairan hingga angka yang tertera pada thermometer menunjukkan nilai yang konstan/stabil.

Salinitas perairan diukur dengan menggunakan handrefraktometer, yaitu dengan cara meneteskan sampel air laut kedalam prisma handrefraktometer, kemudian tutup plat cahaya dan dicatat nilai salinitas yang tercantum pada handrefraktometer.

Pengambilan data $\mathrm{pH}$ dilakukan setiap stasiun penelitian dengan cara mencelupkan potongan kertas $\mathrm{pH}$ Indikator kedalam sampel air laut kemudian dikeringkan. Selanjutnya kertas $\mathrm{pH}$ dicocokkan warnanya dengan indikator warna $\mathrm{pH}$ untuk mendapatkan nilai $\mathrm{pH}$ air laut.

Pengambilan data kecepatan arus dilakukan di setiap titik stasiun penelitian. Layangan arus dilepaskan selaras dengan mengaktifkan stopwacth. Data kecepatan arus yang diperoleh selama penelitian akan diketahui dengan cara menghitung selama waktu (t) yang dibutuhkan layangan arus untuk menempuh jarak (s) dengan rumus sebagaimana persamaan (1) :

$\mathrm{v}=\frac{\mathrm{s}}{\mathrm{t}}$

Dimana :

$\mathrm{v}=$ Kecepatan arus $(\mathrm{m} / \mathrm{det})$ 
$\mathrm{s}=$ Jarak tempuh layangan arus $(\mathrm{m})$

$\mathrm{t}=$ Waktu yang dibutuhkan layang arus (det)

Pengukuran kecerahan perairan dilakukan pada setiap stasiun penelitian. Pengukuran dilakukan dengan cara menenggelamkan secchi disk setiap titik pengambilan kemudian mengukur panjang tali secchi disk pada saat pengamatan.

Data kedalaman di setiap stasiun penelitian menggunakan Depth Gauge pada regulator alat SCUBA yaitu melihat arah jarum pada Depth Gauge yang menunjukan angka kedalaman pada saat melakukan penyelaman dalam pengambilan data.

Pengambilan data spons dilakukan dengan menggunkan metode belt transect dengan panjang $70 \mathrm{~m}$ dan lebar $2 \mathrm{~m}$ sehingga luas pengamatan $140 \mathrm{~m}^{2}$. pengambilan data dilakukan 2 kali pengulangan, dengan menempatkan transek sejajar garis pantai di daerah reef flat hingga daerah reef slope. Dalam transek tersebut dihitung jumlah masing-masing jenis spons yang terdapat di dalam transek kemudian identifikasi jenis spons dilakukan secara langsung dilapangan, dan pengambilan foto sebagai alat bantu identifikasi. Pengamatan dilakukan untuk melihat keanekaragaman jenis spons berdasarkan kriteria jenis spons yaitu secara mata telanjang (makroskopis). Berdasarkan deskripsi lokasi, kedalaman, bentuk luar, permukaan dan warna di dalam area pengamatan. Berdasarkan buku identifikasi (Patrick dan Charles, 1995). Sedangkan metode koleksi bebas sebagai data tambahan biodiversitas spons yang dilihat di luar transek.

\section{Analisis Data}

Dalam menghitung komposisi jenis spons digunakan rumus sebagai berikut (Odum, 1996) :

$\mathrm{Pi}=\frac{n i}{N} \times 100 \%$

Dimana $: \mathrm{Pi}=$ Presentae tiap jenis $(\%), \mathrm{ni}=$ Jumlah individu spesies, $\mathrm{N}=$ Jumlah total individu.

Indeks keanekaragaman (H') digunakan indeks keakaragaman Shannon-Wienner untuk mendapatkan gambaran populasi organisme secara matematis agar mempermudah analisis informasi jumlah individu masing-masing spesies dalam suatu komunitas (Odum, 1996).

$\mathrm{H}^{\prime}=-\sum\left(\frac{n i}{\mathrm{~N}} \ln \frac{n i}{\mathrm{~N}}\right)$
Dimana :

$\mathrm{H}^{\prime}=$ Indeks keanekaragaman jenis Shannon Wienner

$\mathrm{Pi}=\mathrm{ni} / \mathrm{N}$, perbandingan antara jumlah individu spesies ke-i dengan jumlah total individu $=($ Proporsi jenis ke-i)

$\mathrm{ni}=$ umlah individu jenis ke-i

$\mathrm{N}=$ jumlah total individu seluruh jenis

Nilai indeks keanekaragaman Shannon-

Weiner mempunyai kisaran nilai tertentu menurut (Odum, 1996) yaitu sebagai berikut: $0 \leq \mathrm{H}^{\prime}<1=$ tingkat keanekaragaman jenis rendah. $1 \leq \mathrm{H}^{\prime}<3=$ Tingkat keanekaragaman jenis sedang. $\mathrm{H}^{\prime} \geq 3=$ tingkat keanekaragaman jenis tinggi

Kepadatan individu spons di definisikan sebagai jumlah individu dibagi luas daerah pengamatan di setiap stasiun. Kepadatan dihitung dengan menggunakan rumus Brower dan Zar (1997) pada persamaan (4) yaitu :

$\mathrm{N}=\frac{n}{A}$

Dimana :

$\mathrm{N}=$ Kepadatan Individu (ind $/ \mathrm{m}^{2}$ )

$\mathrm{n}=$ Jumlah individu yang diperoleh tiap stasiun

$\mathrm{A}=$ Luas daerah pengamatan $\left(\mathrm{m}^{2}\right)$

Nilai kepadatan spons mempunyai kisaran nilai tertentu yaitu sebagai berikut:

Di $<0,1=$ kepadatan rendah

$0,1<$ Di $>0,2=$ kepadatan sedang

Di $>0,3=$ kepadatan tinggi

Frekuensi kemunculan spons diambil berdasarkan jumlah munculnya setiap jenis spons pada setiap stasiun pengamatan digunakan rumus sebagai berikut Odum (1993), pada persamaan (5) yaitu :

$\mathrm{F}=\frac{\sum \mathbf{m}}{\sum \mathbf{S t}} \times 100 \%$

Dimana :

$\mathrm{F}=$ frekuensi kemunculan setiap jenis spons

$\sum \mathrm{m}=$ jumlah kemunculan jenis ke-i pada setiap stasiun

$\sum$ St $=$ jumlah stasiun

Indeks keseragaman jenis dihitung dengan indeks keseragaman (E). Rumusnya adalah sebagai berikut (Odum, 1996).

$\mathrm{E}=\frac{\mathrm{H}^{\prime}}{\mathrm{H}^{\prime} \max }$

Dimana :

$\mathrm{E}=$ Indeks keseragaman, $\mathrm{H}^{\prime}=$ Indeks keanekaragaman jenis, Hmax = Jumlah jenis organisme $(\ln S), S=$ jumlah spesies.

Kriteria indeks keseragaman jenis yaitu (Odum, 1996): 
$0 \leq \mathrm{E}<0,3=$ Tingkat keseragaman jenis rendah. $0,3 \leq \mathrm{E}<0,6=$ Tingkat keseragaman jenis sedang. $0,6 \leq \mathrm{E}>1=$ Tingkat keseragaman jenis tinggi

Dominansi jenis dihitung dengan menggunakan rumus adalah sebagai berikut (Odum, 1996).

$\mathrm{D}=\sum_{i=1}^{\mathrm{s}}(\mathrm{ni} / \mathrm{N})^{2}$

Dimana :

$\mathrm{D}=$ indeks dominansi

$\mathrm{ni}=\quad$ kelimpahan spons jenis ke-i

$\mathrm{N}=$ kelimpahan total seluruh jenis spons

Kriteria indeks dominansi yaitu (Odum, 1996):

$0 \leq \mathrm{D}<0,3=$ Tingkat dominansi jenis rendah

$0,3 \leq \mathrm{D}<0,6=$ Tingkat dominansi jenis sedang

$0,75<\mathrm{D}<1,0=$ Tingkat dominansi jenis tinggi

\section{Hasil dan Pembahasan}

Berdasarkan hasil penelitian ini ditemukan 13 genus spons yang berasal dari 16 spesies yang terdapat di ketiga stasiun penelitian yakni : Petrosia, Xestospongia, Callyspongia, Haliclona, Ircinia, Carteriospongia, Phyllospongia, Chondropsis, Melophlus, Stylissa, Axinyssa, Stylotella, Theonella. Pada daerah reef flat dan daerah reef slope spons yang banyak ditemukan secara keseluruhan dari setiap stasiun adalah spons dari genus Petrosia.
Spons dari genus Petrosia memiliki nilai yang dominan lebih tinggi diketiga stasiun penelitian pada daerah reef flat dan daerah reef slope dikarenakan spons dari genus Petrosia yaitu jenis Petrosia sp. dapat hidup dimana saja, hal ini sesuai dengan pernyataan (Faundez and Valentine, 2002) yang menyatakan bahwa spons dari famili petrosiidae merupakan famili yang umum ditemukan di perairan dangkal dan dalam dengan temperatur yang relatif hangat.

Selain itu spons dari genus Xestospongia, Callyspongia, Haliclona, Ircinia, Carteriospongia, Phyllospongia, Chondropsis, Melophlus, Stylissa, Axinyssa, Stylotella, theonella merupakan spons yang memiliki nilai yang rendah di ketiga staiun penelitian pada daerah reef flat dan daerah reef slope dikarenakan ada beberapa jenis spons yang hidup pada daerah-daerah tertentu.

Spons dengan jumlah yang besar umumnya dipengaruhi oleh ruang untuk tumbuh. Namun pada beberapa genus yang tidak dominan umumnya tumbuh disela-sela karang dan bentuknya keci dan pendek sehingga memungkinkan untuk dapat bersaing dengan organism lain. Hal ini sesuai dengan pernyataan (Amir dan Budiyanto, 1996) bahwa spons dapat berkompetensi dengan alga dan karang dalam mendapatkan cahaya dimana spons dapat tumbuh di antara sela-sela karang.

Tabel 1. Komposisi jenis spons pada daerah reef flat

\begin{tabular}{|c|c|c|c|c|}
\hline \multirow{2}{*}{ No } & \multirow{2}{*}{ Jenis Spons } & \multicolumn{3}{|c|}{ Komposisi Jenis Spons (\%) } \\
\hline & & Stasiun I & Stasiun II & Stasiun III \\
\hline 1 & Petrosia sp. & 22 & 29 & 24 \\
\hline 2 & Melophlus sarassinorum & 14 & 14 & 5 \\
\hline 3 & Ircinia sp. & 11 & - & - \\
\hline 4 & Haliclona sp. & 11 & 12 & 10 \\
\hline 5 & Chondropsis kirkii & 11 & 9 & - \\
\hline 6 & Callyspongia sp. & 11 & 6 & 12 \\
\hline 7 & Axinyssa sp. & 8 & - & - \\
\hline 8 & Haliclona amboinensis & 6 & 9 & 10 \\
\hline 9 & Theonella sp. & 6 & - & - \\
\hline 10 & Carteriospongia foliascens & - & - & 1 \\
\hline 11 & Haliclona oculata & - & - & - \\
\hline 12 & Xestospongia sp. & - & 9 & - \\
\hline 13 & Phyllospongia sp. & - & 9 & 27 \\
\hline 14 & Stylissa haurakii & - & 3 & - \\
\hline 15 & Phyllospongia papyracea & - & - & 5 \\
\hline 16 & Styllotella & - & - & 5 \\
\hline
\end{tabular}


Terdapat perbedaan nyata antara kepadataan spons pada daerah reef flat dan kepadatan spons pada daerah reef slope. Oleh karena itu dari hasil yang didapatkan dapat dikatakan bahwa spons yang memiliki kepadatan tertinggi yaitu pada daerah reef flat, daerah reef flat yang dangkal memungkinkan cahaya yang masuk kedalam air lebih banyak dari pada daerah reef slope. Hal ini sesuai dengan pendapat Barnes (1999) dalam Haris (2013), bahwa spons sangat menyukai perairan yang cukup jernih karena spons termasuk plankton feeder.

Pada daerah reef flat kepadatan yang paling tinggi terdapat pada stasiun III dan terendah pada stasiun II. Pada stasiun terletak pada daerah yang dekat dengan vegetasi mangrove hal ini yang menyebabkan spons pada stasiun III lebih padat dari pada stasiun II dan III. Secara umum mangrove memiliki peran penting terhadap daerah pantai, hal ini sesuai dengan pernyataan (Abdul, 2014) bahwa fungsi mangrove yang terpenting bagi daerah pantai adalah menjadi penghubung antara daratan dan lautan. Tumbuhan, hewan dan benda-benda lainnya, dan nutrisi tumbuhan ditransfer ke arah daratan atau ke arah laut melalui mangrove. Selain itu mangrove juga berperan sebagai filter untuk mengurangi efek yang merugikan dari perubahan lingkungan utama, dan sebagai sumber makanan bagi biota laut.

Tabel 2. Komposisi jenis spons pada daerah reef slope

\begin{tabular}{llccc}
\hline \multirow{2}{*}{ No } & \multicolumn{1}{c}{ Jenis Spons } & \multicolumn{3}{c}{ Komposisi Jenis Spons (\%) } \\
\cline { 2 - 5 } & Petrosia sp. & 23 & Stasiun II & Stasiun III \\
\hline 1 & Callyspongia sp. & 23 & 36 & - \\
2 & 18 & - & 20 \\
3 & Phyllospongia papyracea & 12 & - & - \\
4 & Haliclona sp. & 6 & 15 & 10 \\
5 & Carteriospongia foliascens & 6 & - & - \\
6 & Axinyssa sp. & 6 & - & - \\
7 & Haliclona amboinensis & 6 & 14 & 20 \\
8 & Ircinia sp. & - & 14 & - \\
9 & Xestospongia sp. & - & 14 & - \\
10 & Phyllospongia sp. & - & 7 & 10 \\
11 & Stylissa haurakii & - & - & \\
12 & Melophlus sarassinorum & & & \\
\hline
\end{tabular}

Tabel 3. Kepadatan spons pada daerah reef flat

\begin{tabular}{llccc}
\hline \multirow{2}{*}{ No } & \multicolumn{1}{c}{ Jenis Spons } & \multicolumn{3}{c}{ Kepadatan Spons (ind $/ \mathrm{m}^{2}$ ) } \\
\cline { 3 - 5 } & Petrosia sp. & 0,03 & Stasiun II & Stasiun III \\
\hline 1 & Melophlus sarassinorum & 0,02 & 0,04 & 0,04 \\
3 & Ircinia sp. & 0,01 & 0,02 & 0,01 \\
4 & Haliclona sp. & 0,01 & - & - \\
5 & Chondropsis kirkii & 0,01 & 0,01 & 0,01 \\
6 & Callyspongia sp. & 0,01 & - & - \\
7 & Axinyssa sp. & 0,01 & 0,01 & 0,02 \\
8 & Haliclona amboinensis & 0,01 & - & - \\
9 & Theonella sp. & 0,01 & - & 0,01 \\
10 & Carteriospongia foliascens & - & - & - \\
11 & Haliclona oculata & - & 0,01 & 0,00 \\
12 & Xestospongia sp. & - & 0,01 & - \\
13 & Phyllospongia sp. & - & 0,01 & - \\
14 & Stylissa haurakii & - & 0,01 & 0,04 \\
15 & Phyllospongia papyracea & - & 0,00 & - \\
16 & Styllotella & - & - & 0,01 \\
\hline Total & 0,13 & - & 0,01 \\
\hline Jumlah Spesies & 9 & 0,12 & 0,15 \\
\hline
\end{tabular}


Tabel 3. Kepadatan spons pada daerah reef slopee

\begin{tabular}{llccc}
\hline \multirow{2}{*}{ No } & \multirow{2}{*}{ Jenis Spons } & \multicolumn{3}{c}{ Kepadatan Spons (ind $/ \mathrm{m}^{2}$ ) } \\
\cline { 3 - 5 } & & Stasiun I & Stasiun II & Stasiun III \\
\hline 1 & Petrosia sp. & 0,01 & 0,02 & - \\
2 & Callyspongia sp. & 0,01 & - & 0,01 \\
3 & Phyllospongia papyracea & 0,01 & - & - \\
4 & Haliclona sp. & 0,01 & 0,01 & 0,01 \\
5 & Carteriospongia foliascens & 0,00 & - & 0,00 \\
6 & Axinyssa sp. & 0,00 & - & - \\
7 & Haliclona amboinensis & 0,00 & - & - \\
8 & Ircinia sp. & 0,00 & 0,01 & 0,01 \\
9 & Xestospongia sp. & - & 0,01 & - \\
10 & Phylospongia sp. & - & 0,01 & 0,00 \\
11 & Stylissa haurakii & - & 0,00 & - \\
12 & Melophlus sarassinorum & - & - & 0,00 \\
\hline Total & 0,06 & 0,05 & 0,03 \\
\hline Jumlah Spesies & 8 & 6 & 6 \\
\hline
\end{tabular}

Tabel 4. Indeks keanekargaman, indeks keseragaman, dan indeks dominansi di daerah reef flat.

\begin{tabular}{cccc}
\hline Stasiun & $\begin{array}{c}\text { Indeks Keanekaragaman } \\
\left(\mathrm{H}^{\prime}\right)\end{array}$ & $\begin{array}{c}\text { Indeks } \\
\text { Keseragaman }(\mathrm{E})\end{array}$ & $\begin{array}{c}\text { Indeks } \\
\text { Dominansi (C) }\end{array}$ \\
\hline I & 2,11 & 0,96 & 0,13 \\
II & 2,02 & 0,92 & 0,16 \\
III & 1,94 & 0,88 & 0,17 \\
\hline
\end{tabular}

Tabel 5. Indeks keanekargaman, indeks keseragaman, dan indeks dominansi di daerah reef slope.

\begin{tabular}{cccc}
\hline \multirow{2}{*}{ Stasiun } & $\begin{array}{c}\text { Indeks Keanekaragaman } \\
\left(\mathrm{H}^{\prime}\right)\end{array}$ & $\begin{array}{c}\text { Indeks } \\
\text { Keseragaman }(\mathrm{E})\end{array}$ & $\begin{array}{c}\text { Indeks } \\
\text { Dominansi (C) }\end{array}$ \\
\hline I & 1,91 & 0,92 & 0,17 \\
II & 1,67 & 0,93 & 0,21 \\
III & 1,74 & 0,97 & 0,19 \\
\hline
\end{tabular}

Tabel 6. Frekuensi kemunculan spons pada daerah reef flat.

\begin{tabular}{lcccc}
\hline \multicolumn{1}{c}{ Jenis Spons } & \multicolumn{3}{c}{ Stasiun } & \multirow{2}{*}{ F $(\%)$} \\
\cline { 2 - 4 } & I & II & III & 100 \\
\hline Petrosia sp. & + & + & + & 100 \\
Melophlus sarassinorum & + & + & + & 33 \\
Ircinia sp. & + & - & - & 100 \\
Haliclona sp. & + & + & + & 33 \\
Chondropsis kirkii & + & - & - & 100 \\
Callyspongia sp. & + & + & + & 33 \\
Axinyssa sp. & + & - & - & 67 \\
Haliclona amboinensis & + & - & + & 33 \\
Theonella sp. & + & - & - & 67 \\
Carteriospongia foliascens & - & + & + & 33 \\
Haliclona oculata & - & + & - & 67 \\
Xestospongia sp. & - & + & - & 33 \\
Phylospongia sp. & - & + & + & 33 \\
Stylissa haurakii & - & + & - & \\
Phyllospongia papyracea & - & - & + & + \\
Styllotella & - & - & + & \\
\hline
\end{tabular}


Selain kondisi habitat, kecepatan arus juga mempengaruhi kepadatan spons di Perairan Lalanu. Pada stasiun III diperoleh kecepatan arus sebesar $0,04 \mathrm{~m} / \mathrm{dtk}$ nilai ini merupakan nilai yang sesuai untuk pertumbuhan spons. Pernyataan ini sesuai dengan pernyataan (Storr, 1976 dalam Suharyanto, 1998) bahwa spons dapat tumbuh normal pada cepatan arus kurang dari 0,6 $\mathrm{m} / \mathrm{dtk}$.

Selain stasiun III, stasiun I juga memiliki kepadatan spons yang terbilang tinggi. Hal ini dikarenakan, stasiun I terletak pada daerah laut lepas yang memiliki arus yang cukup kuat yaitu $0,08 \mathrm{~m} / \mathrm{dtk}$. Arus yang kuat dapat membawa suplay makanan dan unsur-unsur nutrient. Menurut (suharyanto, 1998) bahwa arus dari laut lepas dapat mensuplai banyak makanan dan mempertinggi difusi oksigen dari udara bebas.

Spons membutuhkan arus yang kuat untuk membantu membuang zat buangan spons menjauh dari tubuhkannya karena zat yang dikeluarkan bukan lagi berisi makanan melainkan sampah nitrogen. Hal ini sesuai dengan pernyataan (Romimohtarto dan Juwana, 2001) bahwa spons hidup di perairan yang bersirkulasi baik, karenanya spons ditemukan pada perairan yang jernih bukan yang keruh. Arus air yang lewat melalui spons membawa serta zat buangan dari tubuh spons, maka penting agar air yang keluar melalui osculum dibuang jauh dari badannya karena air ini sudah sudah tidak berisi makanan lagi, tetapi mengandung asam karbonat dan sampah nitrogen yang beracun bagi hewan tersebut.

Pada stasiun II merupakan stasiun yang memiliki kepadatan spons paling rendah dari stasiun I dan stasiun III. Hal ini diduga karena letak stasiun II yang berada tidak jauh dari kaki mulut sungai sehingga meyebabkan rendahnya kepadatan di stasiun ini. Jika dilihat dari kondisi perairannya (tabel. 11) diduga bahwa salinitas dan kecepatan arus merupakan faktor lain yang menyebabkan rendahnya kepadatan spons di stasiun II. Nilai salinitas yang diperoleh pada stasiun II yaitu 34 ppt dan kecepatan arusnya diperoleh $0,07 \mathrm{~m} / \mathrm{dtk}$. Namun, nilai yang diperoleh masih termasuk dalam batas toleransi spons untuk hidup.

Pada daerah reef slope dapat dilihat bahwa kepadatan yang didapatkan berbeda jauh dengan daerah reef flat. Jika dikaitkan dengan parameter perairan yang ada, antara reef flat dan reef slope memiliki nilai parameter yang tidak jauh berbeda karena jarak pengambilan data antara reef flat dan reef slope tidak terlalu jauh.

Kepadatan spons yang didapatkan pada stasiun I memiliki kepadatan yang tinggi dibandingkan stasiun II dan stasiun III, hal ini dikarenakan kondisi substrat yang ada pada setiap stasiun berbeda-beda. pada umumnya stasiun I, II, dan III pada daerah reef slope memiliki substrat yang sama disetiap stasiunnya yaitu patahan karang (Rubble). Ini dikarenakan pernah dilakukannya penangkapan ikan yang menggunkan alat tidak ramah lingkungan seperti bom, sehingga karang yang ada menjadi rusak. Menurut DKTNL (2006), bahwa penangkapan ikan dengan menggunkan bom serta bahan kimia dapat menjadi salah satu penyebab kerusakan terumbu karang.

Tabel 7. Frekuensi kemunculan spons pada daerah reef slope.

\begin{tabular}{lcccc}
\hline \multicolumn{1}{c}{ Jenis Spons } & \multicolumn{3}{c}{ Stasiun } & \multirow{2}{*}{ F (\%) } \\
\cline { 2 - 4 } & I & II & III & 67 \\
Petrosia sp. & + & + & - & 67 \\
Callyspongia sp. & + & - & + & 67 \\
Phyllospongia papyracea & + & - & + & 100 \\
Haliclona sp. & + & + & + & 33 \\
Carteriospongia foliascens & + & - & - & 33 \\
Axinyssa sp. & + & - & - & 33 \\
Haliclona amboinensis & + & - & - & 100 \\
Ircinia sp. & + & + & + & 33 \\
Xestospongia sp. & - & + & - & 67 \\
Phylospongia sp. & - & + & + & 33 \\
Stylissa haurakii & - & + & - & 33 \\
Melophlus sarassinorum & - & - & + & \\
\hline
\end{tabular}


Tabel 8. Hasil analisis parameter kualitas air

\begin{tabular}{lccc}
\hline Parameter kualitas air & Stasiun I & Stasiun II & Stasiun III \\
\hline Kecepatan Arus (m/dtk) & 0.08 & 0.07 & 0.04 \\
Salinitas (ppt) & 35 & 34 & 35 \\
Kedalaman (m) & 5 dan 7 & 5 dan 7 & 5 dan 7 \\
Suhu $\left({ }^{\circ} \mathrm{C}\right)$ & 29 & 30 & 30 \\
Kecerahan $(\%)$ & 100 & 100 & 100 \\
pH & 7 & 7 & 7 \\
\hline
\end{tabular}

Sehingga pada stasiun I ditemukan banyaknya hamparan patahan karang, namun dilihat dari kondisi habitat yang sudah ada ditemukannya karang yang sudah mulai hidup serta spons yang mulai banyak ditemukan di stasiun I sehingga diduga pada stasiun I tidak dilakukannya lagi penangkapan ikan di daerah titik stasiun ini. Pada stasiun II kondisi perairannya tidak jauh berbeda dengan kondisi perairan yang ada di stasiun I, hal ini yang menyebabkan kepadatan spons yang ada di stasiun I, dan II tidak jauh berbeda. Kepadatan terendah pada daerah reef slope terdapat pada stasiun III dilihat dari kondisi perairan yang memiliki patahan karang yang lebih banyak dibandingkan stasiun I dan II. Pada saat pengambilan data masih terdengar adanya kegiatan pengeboman di titik stasiun ini sehingga hal ini diduga menjadi faktor penyebab rendahnya kepadatan spons di stasiun III.

Indeks keankearagaman (H') dapat digunakan untuk mengukur kepadatan komunitas berdasarkan jumlah jenis spesies pada suatu stasiun. Semakin banyak jumlah spesies yang didapatkan maka komunitas yang didapatkan juga semakin beragam. Nilai indeks keanekaragaman spons di Perairan Lalanu pada daerah reef flat berkisar antara 1,94 - 2,11. Nilai yang diperoleh masuk dalam kategori sedang.

Tabel 8 pada daerah reef slope didapatkan nilai indeks keanekaragaman spons dengan kisaran antara 1,67 - 1,91. Nilai yang diperoleh masuk dalam kategori sedang. Nilai indeks keanekaragaman yang diperoleh pada daerah reef flat dan reef slope tidak terlalu jauh, hal ini dikarenakan perbedaan jumlah jenis dan individu pada setiap stasiun selain itu perbedaan kedalaman dan letak titik stasiun diduga dapat mempengaruhi nilai indeks keanekaragaman.

Indeks

keseragaman

menggambarkan ukuran jumlah individu antara spesies dalam suatu komunitas. Semakin merata penyebaran individu antar spesies, maka keseimbangan ekosistem akan makin meningkat. Pada daerah reef flat nilai indeks keseragaman spons berkisar antara 0,88 - 0,96. Nilai yang diperoleh masuk dalam kategori tinggi. Nilai indeks keseragaman spons pada daerah reef slope berkisar antara 0,92 - 0,97 dengan kategori tinggi. Nilai indeks keseragaman spons yang didapatkan antara reef flat dan reef slope memiliki kisaran nilai tidak jauh berbeda. Indek keseragaman spons yang didapatkan dengan kategori tinggi dapat diartikan bahwa spons di Perairan Lalanu masih dalam komunitas yang stabil.

Hal ini dikarenakan karakteristik habitat yang ada antara reef flat dan reef slope memiliki substrat yang hampir sama yaitu patahan karang namun dengan tingkat patahan yang berbeda-beda. Selain karakteristik habitat, jika dilihat pada Tabel 8 faktor kualitas perairannya juga tidak jauh berbeda.

Jumlah individu jenis spons yang didapatkan pada setiap stasiun memiliki jumlah yang hampir sama rata, sehingga tidak terdapat satupun jenis spons yang mendominasi di perairan tersebut.

Frekuensi kemunculan spons pada daerah reef flat didapatkan spons jenis Petrosia sp., M. sarassinorum, Haliclona sp., dan Callyspongia sp., dengan frekuensi kemunculan $100 \%$ yang artinya spons jenis ini muncul di ketiga stasiun penelitian. Spons jenis $H$. amboinensis, C. foliascens, dan Phylospongia sp., frekuensi kemunculannya $67 \%$ yang artinya spons jenis ini hanya muncul di dua titik stasiun penelitian dan spons jenis Ircinia sp., Chondropsis kirkii,Theonella sp., H. oculata, Xestopongia sp., S. haurakii, P. papyracea, dan Styllotella frekuensi kemunculannya $33 \%$ yang artinya spons jenis ini hanya muncul di satu titik stasiun penelitian.

Spons yang memiliki frekuensi kemunculan $100 \%$ diduga memiliki toleransi yang tinggi terhadap kondisi lingkungan yang ada. Spons jenis Petrosia sp. mampu 
beradaptasi pada kondisi perairan yang tidak sesuai dengan kondisi habitat tempat dia hidup. Hal ini sesuai dengan pernyataan (De Voogd, 2005) bahwa spons Petrosia biasanya terdapat di perairan dangkal hingga perairan sampai kedalaman 45 meter. Spons ini juga dapat hidup pada habitat berkarang, baik karang hidup maupun mati, habitat rubble (pecahan karang), dan habitat berpasir. Selain kemuculan spons di ketiga stasiun, ada juga jenis spons yang hanya muncul di satu titik stasiun, diduga spons yang hanya muncul di satu titik stasiun karena spons tersebut tidak mampu menyesuaikan adanya perubahan kondisi perairan yang tidak sesuai untuk dirinya.

Spons jenis Haliclona sp. dan Ircinia sp. muncul di tiga titik stasiun pada daerah reef slope hal ini diduga selain menyukai habitat yang memiliki karang yang bagus, spons ini juga mampu hidup di habitat yang memiliki karang yang kurang bagus atau daerah patahan karang. Beberapa jenis spons dapat hidup hingga pada kedalaman $20 \mathrm{~m}$, namun dengan tingkat toleransi yang berbeda-beda terhadap lingkungan perairan sehingga terdapat spons yang muncul di tiga titik stasiun hingga kemunculannya hanya terdapat di satu titik stasiun. Menurut Suharyanto (2008), beberapa jenis spons dapat hidup pada kedalaman sampai $20 \mathrm{~m}$ asalkan kebutuhan sinar mataharinya cukup.

\section{Simpulan}

Berdaarkan hasil penelitian yang dilakukan di Perairan Lalanu, dapat disimpulkan sebagai berikut :

1. Jenis spons yang ditemukan di Perairan Lalanu 16 jenis, dimana komposisi jenis tertinggi terdapat pada spesies Petrosia sp., baik di daerah reef flat maupun daerah reef slope.

2. Struktur kominitas spons pada Perairan Lalanu di daerah reef flat dan reef slope didapatkan hasil dengan kategori yang sama. Dimana indeks keanekaragaman dengan kategori sedang, indeks keseragaman dengan kategori tinggi dan indeks dominansi dengan kategori rendah.

\section{Daftar Pustaka}

Ackers, R. Graham, and Moss, David, Sponges of The British Isles (Sponge V). Marine Conservation Society.
Bernard E Picton: Northern Ireland (2007)

Alcolado, Pedro, "Reading The Code of Coral Reef Sponge Community Composition and Structure for Environmental Biomonitoring: Some Experience from Cuba", in Porifera Research: Biodiversity, Innovetion and Sustainability. Vol 3, (2003) 3-10.

Amir, I dan Budiyanto, A. 1996. Mengenal sponge laut (Demospongiae) secara umum. Oseana XXI (2): 15-31.

Barnes, D.K.A. 1999. High diversity of tropical intertidal-zone sponges in temperatur, salinity and current extremes. Afr. J. Ecol. 37, 424-434.

De Voogd, N.J.D., 2005. Indonesian Sponges Biodiversity and Marincultured Potential, Geboren te Dodgrecht, Netherlands.

Direktorat Konervasi dan Taman Naional Laut. 2006. Pedoman Pelaksanaan Tranplantai Karang. DKP. 36 p Englih, C.

Faundez, R. Desqueyroux and Valentine, C. Family Petrosiidae. Systema Porifera: A Guide to the Classification of Sponge. New Tork: Kluwer Academic/Plenum Publishers (2002).

Fosifpunila. 2000. Peranan Porifera Bagi Manusia. Klaten: Diakses: 13 November 2013. http://animaldiversity. ummz.umich.edu/site/accounts/ information/Porifera.html.

Haris, 2012. Seksualitas dan perkembangan gamet sponge laut Aaptos Aaptos Schmidt Fakultas Ilmu Kelautan dan Perikanan Universitas Hasanuddin, Makassar. Jurnal Natur Indonesia 14(3): 205-211.

Lariman. 2010. Keanekaragaman Fylum Porifera Dipulau Segajah Kota Bontang Kalimantan Timur. (Skripsi). Universitas Mulawarman. Samarinda.

Romimohtarto, K. dan Juwana S. 2001. Biologi Laut. Ilmu Pengetahuan Tentang Biota Laut. Djambatan. Jakarta. 504 hal.

Suharyanto, A. Parengrengi, dan M. Amin. 1998. Pengamatan Kondisi Terumbu Karang di Perairan Pulau Barranglompo Sulawesi Selatan. Jurnal Penelitian Perikanan Indonesia 7 (3): 12-20. 
Suparno, 2005. Kajian bioaktif spons laut (forifera: demospongiae) suatu peluang alternatif pemanfaatan ekosistem karang indonesia dalam bidang farmas. Makalah Pribadi Falsafah Sains (PPs 7002): Sekolah Pasca Sarjana Institut Pertanian Bogor. 